\title{
Short-term evaluation of Massai grass forage yield and agronomic characteristics and sheep performance under rotational grazing with different pre-grazing canopy heights ${ }^{1}$
}

\section{Avaliação de curto prazo da produção e características de forragem e desempenho de ovinos em capim Massai sob lotação rotativa com diferentes alturas pré-pastejo}

\author{
Rebeca Rocha Cardoso ${ }^{2 *}$; Luciano Fernandes Sousa ${ }^{3}$; Ana Cristina Holanda \\ Ferreira $^{3}$; José Neuman Miranda Neiva ${ }^{3}$; Deborah Alves Ferreira ${ }^{3}$; André \\ Guimarães Maciel e Silva ${ }^{4}$; Elcivan Bento da Nóbrega ${ }^{3}$; Thais Valéria Souza Silva ${ }^{5}$
}

\begin{abstract}
This study aimed to evaluate the morphogenic, structural, chemical characteristics, and forage yield of Massai grass, as well as the performance of sheep under three pre-grazing canopy heights. Eighteen Dorper $\mathrm{x}$ crossbred sheep (12 males and 6 females) were subjected to three pre-grazing canopy heights of Massai grass $(45,35$, and $25 \mathrm{~cm})$. Rotational grazing was adopted, with a fixed rest period of 12 days and occupation of four days. Before placing animals in the paddock, stocking rate was estimated to ensure a reduction of about $50 \%$ in the initial height. Morphogenic and chemical characteristics of forage were evaluated, as well as animal intake and performance. Pasture managed at $25 \mathrm{~cm}$ height induced reductions in stem and sheath sizes, and phyllochron but an increased leaf: stem ratio. However, the pasture cut at $35 \mathrm{~cm}$ above ground promoted an increase in total dry mass and foliar leaf productions, in addition to greater forage availability and daily accumulation. Yet, pastures with a height of $45 \mathrm{~cm}$ had a higher percentage of stem and senescent material, decreasing leaf intake by animals. Among the studied heights, $35 \mathrm{~cm}$ is the most suitable for Massai grass, when used for rearing sheep for meat production under pasture conditions in the northern Tocantins. This is because this management provided a greater availability of good quality forage and thereby increasing weight gains per area in animals.
\end{abstract}

Key words: Chemical composition, Megathyrsus maximus, morphogenesis, Panicum maximum, ruminants.

\section{Resumo}

O objetivo foi avaliar as características morfogênicas, estruturais, bromatológicas e de produção do capim Massai, assim como o desempenho de ovinos sob três alturas pré-pastejo. Foram utilizados 18 ovinos (12 machos e seis fêmeas) mestiços Dorper x sem padrão racial definido (SPRD) pastejando

1 Parte da tese de doutorado da primeira autora.

2 Prof $^{\mathrm{a}} \mathrm{Dr}^{\mathrm{a}}$, Universidade Estadual do Tocantins, UNITINS, Palmas, TO, Brasil. E-mail: rebecarcardoso@outlook.com

3 Profs. Drs., Universidade Federal do Tocantins, UFT, Araguaína, TO, Brasil. E-mail: luciano.sousa@uft.edu.br; anacristinahf@, uft.edu.br; araguaia2007@gmail.com; deborah.alvesferreira@gmail.com; enobrega@uft.edu.br

4 Prof. Dr., Universidade Federal do Pará, UFPA, Castanhal, PA, Brasil. E-mail: andregms@gmail.com

5 Discente do Curso de Doutorado em Ciência Animal Tropical, Universidade Federal do Tocantins, UFT, Araguaina, TO, Brasil. E-mail: tvaleria18@hotmail.com

* Author for correspondence 
em três alturas pré-pastejo em capim Massai, sendo as alturas de $45 \mathrm{~cm}, 35 \mathrm{~cm}$ e $25 \mathrm{~cm}$. Foi adotado o método de lotação rotativa com período de descanso fixo de 12 dias e de ocupação de quatro dias. Antes da entrada dos animais no piquete foi estimada a lotação animal necessária para garantir a redução de aproximadamente $50 \%$ da altura inicial. Avaliou-se as características morfogênicas e a composição bromatológica da forragem e avaliou-se o consumo e desempenho dos animais. A altura de $25 \mathrm{~cm}$ reduziu o alongamento de colmo, o filocrono e o comprimento da bainha e apresentou maior relação folha:colmo, no entanto, o tratamento com $35 \mathrm{~cm}$ de altura pré-pastejo apresentou maior produção de massa seca total e de lâmina foliar, assim como maior oferta de forragem e taxa de acúmulo diária. Já o tratamento com $45 \mathrm{~cm}$ aumentou a porcentagem de colmo e de forragem morta acarretando uma menor apreensão de folhas pelos animais. Os maiores teores de proteína e nutrientes digestíveis totais foram observados no tratamento com $35 \mathrm{~cm}$ e no tratamento com $25 \mathrm{~cm}$ respectivamente. Com base nos resultados apresentados, a altura de $35 \mathrm{~cm}$, entre as alturas de pré-pastejo avaliadas, é a mais indicada para o capim Massai utilizado na criação de ovinos de corte a pasto nas condições do norte do Tocantins, por apresentar maior disponibilidade de alimento, com uma boa qualidade da forrageira e possibilitar maior ganho de peso dos animais por área.

Palavras-chave: Bromatológica, Megathyrsus maximus, morfogênese, Panicum maximum, ruminantes.

\section{Introduction}

The cultivar Massai grass BRA 007102 (Megathyrsus maximus x M. infestum) is suitable for sheep grazing due to its characteristics such as withstanding capacity against close grazing, good regrowth ability, and well-developed root system, which ensures good soil adhesion (AMORIM et al., 2017). However, like other forage grasses, Massai grass yield depends on its ability to regrow leaves and tillers after grazing and restore leaf area and photosynthesis rates, and thus ensuring plant perenniality (COSTA et al., 2016).

Defoliation thresholds should be established for each plant species and climatic condition to avoid extremely low or high mass accumulations, which impairs system perenniality. Besides pasture perenniality, the quality of feed provided for grazing animals should also be considered.

Pasture management needs to be oriented towards factors related to plant, animal, and forage quantity and quality (LIMA et al., 2014). Grass height control is part of such management and influences forage structure and quality due to changes in fiber quantity, which affects food intake dynamics and animal performance (FONTES et al., 2014; VAN SOEST, 1994).

This study aimed to evaluate the morphogenic, structural, chemical, and production characteristics of Massai grass, as well as sheep performance under rotational grazing with three pre-grazing heights.

\section{Material and Methods}

\section{Experimental area characterization}

The experiment was performed at the School of Veterinary Medicine and Animal Science - EMVZ, Federal University of Tocantins - UFT, campus of Araguaina, Tocantins. The procedures were approved by the Ethics Committee on Animal Use of the Federal University of Tocantins (CEUAUFT), under protocol $n^{\circ}$ 23101.002369/2014-28. The experiment was conducted during the rainy season of 2017. Climate data were gathered from a meteorological station located at the EMVZ/UFT campus, during the experimental months in 2017 (Table 1). 
Table 1. Maximum, mean, and minimum temperatures; relative humidity $(\mathrm{RH})$; mean solar radiation; and rainfall data from February to April 2017, obtained from the meteorological station of Araguaína-A021, in Araguaína-TO, Brazil (INMET, 2018).

\begin{tabular}{|c|c|c|c|c|c|c|}
\hline \multirow{2}{*}{ Month } & \multicolumn{3}{|c|}{ Temperature $\left({ }^{\circ} \mathrm{C}\right)$} & \multirow{2}{*}{$\begin{array}{l}\text { RH } \\
(\%)\end{array}$} & \multirow{2}{*}{$\begin{array}{c}\text { Mean solar radiation } \\
\left(\mathrm{kJ} / \mathrm{m}^{2}\right)\end{array}$} & \multirow{2}{*}{$\begin{array}{c}\text { Rainfall } \\
(\mathrm{mm})\end{array}$} \\
\hline & Mean & Max & Min & & & \\
\hline February & 24.8 & 33.9 & 19.5 & 87.3 & 665.0 & 328.8 \\
\hline March & 25.3 & 33.7 & 20.9 & 86.5 & 734.0 & 254.4 \\
\hline April & 25.4 & 34.7 & 20.1 & 86.1 & 691.5 & 204.0 \\
\hline
\end{tabular}

\section{Experimental conditions}

The experiment was performed in an area of 4,812 $\mathrm{m}^{2}$, already grown with Massai grass, and located at the Sheep and Poultry Research Center of the EMVZ/UFT. Local soil was classified as a typic Orthic Quartzarenic Neosol (EMBRAPA, 2013). The experimental design was in randomized blocks with three treatments, four blocks, and repeated measures (three grazing cycles).

Treatments consisted of three pre-grazing heights of Massai grass $(45,35$, and $25 \mathrm{~cm})$. The area was divided into 16 paddocks, subdivided into four blocks for each treatment, totaling 12 experimental paddocks. The remaining four subplots were deferred and managed at heights of 45 and $35 \mathrm{~cm}$ (two for each), which were used in case of the experimental paddocks did not return to their initial heights after the rest period. No additional paddock was needed for $25-\mathrm{cm}$ height treatments since the rest period was long enough for pasture recovery, as observed during the adaptation cycle. Each cycle (subplot) ended as soon as sheep returned to the first paddock. A total of four grazing cycles were evaluated, among which the first was considered as adaptation period.

Treatments consisted of three pre-grazing canopy heights of Massai grass $(45,35$, and $25 \mathrm{~cm})$. The area was divided into 16 paddocks of $301 \mathrm{~m}^{2}$ each. Four paddocks were divided into blocks for each of the three treatments, where the rotational method of grazing was used, totaling 12 experimental paddocks. The remaining four paddocks were deferred and kept at $45 \mathrm{~cm}$ and $35 \mathrm{~cm}$ heights (two paddocks for each height) for using if the experimental paddocks did not reach their initial heights after the rest period. It is worth noting that an additional paddock was not necessary for treatments with $25 \mathrm{~cm}$ height since the rest period was enough for the pasture to return to its initial height, as observed during the adaptation cycle. Each cycle (subplot) was ended as soon as the sheep returned to the first paddock. Four grazing cycles were performed, in which the first cycle was considered the adaptation cycle.

Initially, the first paddocks of each treatment underwent standardization cuts at a height of $15 \mathrm{~cm}$ from ground level, using a backpack brush cutter. While the remaining paddocks were subjected to cuts every four days so that pasture in all plots did not reach the target height at the same time. Secondly, two days after standardization cut, paddocks were fertilized with $76.00 \mathrm{~kg} \mathrm{~N} \mathrm{ha}^{-1}, 14.63 \mathrm{~kg} \mathrm{P}_{2} \mathrm{O}_{5}$ ha1, and $30.38 \mathrm{~kg} \mathrm{~K}_{2} \mathrm{O} \mathrm{ha}{ }^{-1}$, using as sources urea, single superphosphate, and potassium chloride, respectively. Nitrogen fertilization was divided into four dressings at the beginning of each grazing cycle (adaptation and experimental). The total amount of fertilizer intended for the experimental period was $250 \mathrm{~kg} \mathrm{~N} \mathrm{ha}^{-1}$ year $^{-1}, 50 \mathrm{~kg} \mathrm{P}_{2} \mathrm{O}_{5}$ ha $^{-1}$ year ${ }^{-1}$, and 100 $\mathrm{kg} \mathrm{K}_{2} \mathrm{O}$ ha $^{-1}$ year $^{-1}$, considering a seven-month rainy season.

Eighteen 6-month-old Dorper x crossbred sheep were used ( 6 females and 12 males), with a mean weight of $24 \mathrm{~kg} \pm(4)$. The animals were divided into groups with the same number of males and 
females to remove sex effect, distributed among three treatments $(45,35$, and $25 \mathrm{~cm})$. Rotational grazing method adopted had a fixed rest period of 12 days and occupation period of four days. Before placing animals into the paddock, stocking rate was estimated to ensure a reduction of about $50 \%$ in the initial height. Additional intact sheep were used to remove forage mass from plots (45 and $35 \mathrm{~cm}$ ) to standardize pasture during grazing periods. The stocking rate was defined according to pasture production in the adaptation period of each treatment.

Sheep were kept on pasture during daytime (from 7 am to $6 \mathrm{pm}$ ). Thereafter, the animals were taken to separate pens according to treatment, to deter predator attacks at night. Both on pasture and in the pens, the animals had free access to water and mineral mix (Matsuda ${ }^{\circledR}$ Ovino Top Line: 135 to $150 \mathrm{~g} \mathrm{~kg}^{1} \mathrm{Ca}, 65 \mathrm{~g} \mathrm{~kg}^{1} \mathrm{P}, 107 \mathrm{~g} \mathrm{~kg}^{1} \mathrm{Na}, 12 \mathrm{~g} \mathrm{~kg}^{1} \mathrm{~S}$, $30 \mathrm{~g} \mathrm{~kg}^{1} \mathrm{CP}, 100 \mathrm{~g} \mathrm{~kg}^{1} \mathrm{TDN}$ ).

\section{Canopy height}

Herbage heights were controlled during and after grazing until the next cycle begins. Every two days measurements were taken from the tiller base, at ground level, to the middle of the highest leaves in the canopy. Twenty random points were measured in each paddock with the aid of a graduated ruler.

\section{Forage structural and chemical characteristics}

Two samples were collected from a representative area of each paddock. They were cut close to the ground both in pre-grazing and post-grazing for each cycle to measure forage mass. One sample quadrat $(0.5 \times 1 \mathrm{~m})$ was used in the sampling, and samples were packed in plastic bags. Green mass yield (GMY) was determined by weighing the collected samples. However, one sample was used to separate and measure the dry weight of leaf blade (LBDM), stem (SDM), and senescent material
(SMDM), and another sample was taken for total dry matter (TDM). These measures were taken after samples were oven-dried in a forced-air drying oven at $55^{\circ} \mathrm{C}$ for 72 hours. Forage accumulation rate (FAR) was calculated by the equation: FAR = (FFM - IFM)/rest days; wherein: FFM is the final forage mass, and IFM is the initial forage mass in the next cycle. Forage density (FD) was estimated by dividing TDM by the respective canopy height; whereas leaf: stem ratio (L/S) was calculated by dividing LBDM by SDM. Available forage (AF) was given by the difference between TDM and forage dry matter when canopy height reached 50\% (expected post-grazing height after stocking rate adjustments). Forage supply (FS) was determined by dividing the mass of AF a day by $100 \mathrm{~kg}$ animal body weight.

After dried, samples were ground in a Willey mill (1-mm sieve), and dry matter (DM), crude protein $(\mathrm{CP})$, ether extract (EE), and mineral matter (MM) were measured. Neutral detergent fiber (NDF) and acid detergent fiber (ADF) were estimated according to the method of Silva and Queiroz (2002). Levels of total digestible nutrient (TDN) were calculated by the equation used for green forage described by Cappelle et al. (2001): TDN $=-2.49+1.0167$ IVOMD; wherein: IVOMD is the in vitro organic matter digestibility (\%).

\section{Morphogenic characteristics}

The marked tiller technique was used for the monitoring of forage morphogenic characteristics during the rest period. In each paddock, three representative clumps were selected and identified with stakes fixed to the ground. Each clump had four tillers marked with colored wires for differentiation, totaling 48 tillers per treatment in each grazing cycle.

The tillers were measured every two days until the target heights were reached again. Sheath, leaf-blade, stem, and extended-tiller lengths were 
determined using a millimeter ruler. The green area of senescence leaves was measured to the point where the senescence process began. Leaves with more than 50\% senescent area were considered dead. Intact, partially-defoliated, expanded (with exposed ligule), expanding (without exposed ligule) and senescent (with part of leaf blade under senescence) leaves were all considered for analysis. Then, the following variables were obtained:

a) Leaf appearance rate (LAR): the number of leaves emerged in a tiller per unit time, in leaves tiller ${ }^{-1}$ day $^{-1}$.

b) Phyllochron: the time interval between the appearance of successive leaves in each tiller, equates to the inverse of LAR, in days leaf tiller ${ }^{-1}$.

c) Leaf elongation rate (LER): the sum of leaf elongation per tiller divided by the number of evaluation days, in $\mathrm{cm}$ tiller day ${ }^{-1}$.

d) Stem elongation rate (SER): the sum of stem elongation per tiller divided by the number of evaluation days, in $\mathrm{cm}$ tiller day ${ }^{-1}$.

e) Leaf senescence rate (LSR): the difference between initial and final lengths of green tissue divided by the number of evaluation days, in $\mathrm{cm}$ tiller day ${ }^{-1}$.

f) Number of live leaves (NLL): the number of expanded live leaves, including partiallydefoliated green leaves, at the end of the evaluation, in leaves tiller ${ }^{-1}$.

g) Defoliation intensity (DI): the difference between pre- and post-grazing tiller length, in percentage $(\%)$

\section{Animal performance}

Six animals (replicates) per treatment were evaluated for performance. Animal weight gain (WG) was determined by weighing every 7 days, preceded by a 12-hour fast. Average daily weight gain (ADWG) was estimated by dividing WG from the last weighing by the number of evaluation days. Average daily weight gain per area (ADWGA) was calculated by multiplying ADWG by the number of animals per hectare. Stocking rate (SR) was calculated as a product of the number of animals (testers + additional) by the experimental area dimension of each treatment, considering rotational grazing. SR was extrapolated to an animal unit (AU) of $450 \mathrm{~kg}$ per hectare. Grazing efficiency (GE) was estimated by dividing total organic matter intake per treatment by the amount of available forage.

Forage intake was measured using titanium dioxide $\left(\mathrm{TiO}_{2}\right)$ packed in paper bags as a marker. Animals were bolused with 4 grams of $\mathrm{TiO}_{2}$ daily via $1 / 2$-inch flexible PVC tubing for 12 days, seven for adaptation and five for feces collection. Fecal samples were collected directly from the rectum of animals every day early in the morning. These samples were then identified and stored in a freezer. At the end of the experiment, they were oven-dried in a forced-air drying oven at $55{ }^{\circ} \mathrm{C}$ for 72 hours until constant weight, processed in a Willey mill (1-mm sieve), and then analyzed according to the method of Myers et al. (2004).

Fecal output (FO) was calculated according to the formula described by Rodríguez et al. (2006):

FO $\left(\mathrm{kg} \mathrm{OM} \mathrm{day}{ }^{-1}=\frac{\text { Marker supplied }\left(\mathrm{g} \mathrm{day}^{-1}\right)}{[\text { Marker in feces }]\left(\mathrm{g} \mathrm{kg}^{-1} \mathrm{OM}\right)}\right.$

Organic matter intake (OMI; in kg OM day ${ }^{-1}$ ) was determined by the following equation:

Total OMI $\left(\mathrm{kg} \mathrm{DM}\right.$ day $\left.^{-1}\right)=(\mathrm{FO}) /(1$ - IVOMD $)$

Wherein:

Total OMI: is the total organic matter intake $(\mathrm{kg}$ $\left.\mathrm{OM} \mathrm{day}^{-1}\right)$

IVOMD: is the in vitro organic matter digestibility (\%); and

FO: is the fecal output $\left(\mathrm{kg} \mathrm{OM} \mathrm{day}{ }^{-1}\right)$. 
In vitro organic matter digestibility (IVOMD) was determined by the technique of Tilley and Terry (1963) as modified by Goering and Van Soest (1970). Samples of $200 \mathrm{mg}$ forage were placed into heat-sealed nylon-filter bags (F57-ANKOM $\left.{ }^{\circledR}\right)$ and incubated with buffer solution and rumen fluid in graduated syringes. The samples were incubated for 48 hours at $39{ }^{\circ} \mathrm{C}$ in an anaerobic medium. After fermentation, they were washed in neutral detergent solution. As sources of rumen fluid, three rumenfistulated cattle with an average body weight of about $400 \mathrm{~kg}$ and exclusively fed pasture were used.

\section{Statistical analyses}

For pasture-related variables, the experimental design was in randomized blocks with three treatments (paddocks) divided into four blocks and repeated measures (three grazing cycles). For animal-related variables, the experimental design was completely randomized, with each animal considered a replicate. The statistical analyses were performed using the Statistical Analysis System software (SAS INSTITUTE, 1999). First, normality (Shapiro-Wilk) and homoscedasticity (Levene) assumptions were analyzed. Then, Pearson's correlation coefficients (STEEL et al., 1997) and analysis of variance (ANOVA) were performed. Averages were subjected to the Tukey's test at 5\% probability $(\mathrm{P}<0.05)$.

\section{Results and Discussion}

Table 2 shows the actual mean heights and Massai grass yields in pre- and post-grazing. TDM, LBDM, SMDM, and FD were higher in pastures managed at $35 \mathrm{~cm}$ pre-grazing canopy height. These factors and stem mass (SM) yield showed the lowest values in pastures managed at $25 \mathrm{~cm}$. This is because one of the main effects of intense defoliation is forage mass reduction. However, Massai grass managed at $45 \mathrm{~cm}$ had intermediate values of TDM, LBDM, SMDM, and FD. This finding demonstrates that greater heights do not always result in increased forage mass since a lower light availability inside canopy tends to decrease leaf and tiller appearance rates (BERNARDINO; GARCIA, 2009). This occurs because, until their appearance, folded leaves have to cover a longer distance within pseudostems (OLIVEIRA et al., 2007).

Regarding SM yield, treatments managed at $35 \mathrm{~cm}$ and $45 \mathrm{~cm}$ canopy height did not differ statistically. This response can be attributed to a low stem elongation as already observed in Massai grass (GURGEL et al., 2017). However, due to phenotypic plasticity of plants, stem length varies with shading conditions and photosynthetic needs of leaves (FONTES et al., 2014). Since little shading occurred in pastures managed at $25 \mathrm{~cm}$ height due to the intense defoliation, stem yield was considerably reduced.

As for TDM, AF was higher in pastures managed at $35 \mathrm{~cm}$ pre-grazing height and lower in those managed at $25 \mathrm{~cm}$. Higher levels of AF increase selective grazing for leaf blade and directly contributes to increase carrying capacity of pastures (FONTES et al., 2014; SAMPAIO et al., 2016). In pastures with higher $A F$, selective grazing may increase the chances of an animal meeting its nutritional requirements (GARCIA et al., 2016). However, AF itself does not entirely explain animal feed intake, other factors (e.g., FD, L/S ratio, SDM, and SMDM) should also be considered (EMERENCIANO NETO et al., 2016). 
Table 2. Mean canopy height, total dry matter available (TDM), leaf blade dry matter (LBDM), stem dry matter (SDM), senescent material dry matter (SMDM), leaf: stem ratio (L/S), available forage (AF), forage supply (FS), forage density (FD), and forage accumulation rate (FAR) of Megathyrsus maximus x M. infestum cv Massai according to the pre-grazing heights. Averages of three cuttings.

\begin{tabular}{|c|c|c|c|c|c|}
\hline \multicolumn{6}{|c|}{ Pre-grazing } \\
\hline \multirow{2}{*}{ Factor } & \multicolumn{3}{|c|}{ Treatment $(\mathrm{cm})$} & \multirow{2}{*}{$\operatorname{Pr}>F$} & \multirow{2}{*}{$\mathrm{CV} \%$} \\
\hline & 45 & 35 & 25 & & \\
\hline Canopy height $(\mathrm{cm})$ & $46.75 \mathrm{a}$ & $36.50 \mathrm{~b}$ & $27.00 \mathrm{c}$ & $<.0001 * *$ & 5.86 \\
\hline TDM $\left(\mathrm{kg} \mathrm{ha}^{-1}\right)$ & $5800.00 \mathrm{~b}$ & $6600.00 \mathrm{a}$ & $1980.00 \mathrm{c}$ & $<.0001 * *$ & 17.76 \\
\hline $\operatorname{LBDM}\left(\mathrm{kg} \mathrm{ha}^{-1}\right)$ & $1450.00 \mathrm{~b}$ & $1931.70 \mathrm{a}$ & $1100.00 \mathrm{c}$ & $<.0001 * *$ & 17.76 \\
\hline $\operatorname{SDM}\left(\mathrm{kg} \mathrm{ha}^{-1}\right)$ & $2738.89 \mathrm{a}$ & $2897.56 \mathrm{a}$ & $440.00 \mathrm{~b}$ & $0.0022 * *$ & 30.26 \\
\hline $\operatorname{SMDM}\left(\mathrm{kg} \mathrm{ha}^{-1}\right)$ & $1611.11 \mathrm{~b}$ & $1770.73 a$ & $440.00 \mathrm{c}$ & $<.0001 * *$ & 19.56 \\
\hline $\mathrm{L} / \mathrm{S}$ & $0.53 \mathrm{c}$ & $0.67 \mathrm{~b}$ & $2.5 \mathrm{a}$ & $<.0001 * *$ & 20.87 \\
\hline $\mathrm{AF}(\mathrm{kg})$ & $2260.00 \mathrm{~b}$ & $3060.00 \mathrm{a}$ & $950.00 \mathrm{c}$ & $0.0368 *$ & 8.29 \\
\hline FS $(\%)$ & $5.65 \mathrm{~b}$ & $7.65 \mathrm{a}$ & $2.38 \mathrm{c}$ & $<.0001 * *$ & 2.34 \\
\hline $\mathrm{FD}\left(\mathrm{kg} \mathrm{cm} \mathrm{ha}^{-1}\right)$ & $128.89 b$ & $188.57 \mathrm{a}$ & $79.20 \mathrm{c}$ & $<.0001 * *$ & 17.76 \\
\hline FAR $\left(\mathrm{kg} \mathrm{day}^{-1}\right)$ & $47.08 \mathrm{~b}$ & $63.75 \mathrm{a}$ & $19.79 \mathrm{c}$ & $<.0001 * *$ & 18.36 \\
\hline \multicolumn{6}{|c|}{ Post-grazing } \\
\hline \multirow{2}{*}{ Factor } & \multicolumn{3}{|c|}{ Treatment $(\mathrm{cm})$} & \multirow{2}{*}{$\operatorname{Pr}>F$} & \multirow{2}{*}{$\mathrm{CV} \%$} \\
\hline & 45 & 35 & 25 & & \\
\hline Canopy height & 23.50 & 18.50 & 13.50 & $<.0001 * *$ & 7.45 \\
\hline TDM $\left(\mathrm{kg} \mathrm{ha}^{-1}\right)$ & $3540.00 \mathrm{a}$ & $3540.00 \mathrm{a}$ & $1030.00 \mathrm{~b}$ & $0.0029 * *$ & 25.76 \\
\hline $\operatorname{LBDM}\left(\mathrm{kg} \mathrm{ha}^{-1}\right)$ & $590.00 \mathrm{a}$ & $570.97 b$ & $321.88 \mathrm{c}$ & $<.0001 * *$ & 17.76 \\
\hline $\operatorname{SDM}\left(\mathrm{kg} \mathrm{ha}^{-1}\right)$ & $1888.00 \mathrm{~b}$ & $2055.48 \mathrm{a}$ & $386.25 \mathrm{c}$ & $<.0001 * *$ & 29.45 \\
\hline $\operatorname{SMDM}\left(\mathrm{kg} \mathrm{ha}^{-1}\right)$ & $1062.00 \mathrm{a}$ & $913.55 b$ & $321.88 \mathrm{c}$ & $<.0001^{* *}$ & 18.98 \\
\hline $\mathrm{L} / \mathrm{S}$ & $0.31 \mathrm{~b}$ & $0.28 \mathrm{c}$ & $0.83 \mathrm{a}$ & $<.0001 * *$ & 18.54 \\
\hline $\mathrm{FD}\left(\mathrm{kg} \mathrm{cm} \mathrm{ha}{ }^{-1}\right)$ & $160.91 b$ & $208.24 \mathrm{a}$ & $83.83 \mathrm{c}$ & $<.0001 * *$ & 20.12 \\
\hline
\end{tabular}

$\mathrm{CV}=$ Coefficient of variation. Means followed by different letters within the same line differ from each other by the Tukey's test $(\mathrm{P}<0.05)$.

The optimum L/S ratio was observed in pastures managed at $25 \mathrm{~cm}$ height, followed by treatments managed at $35 \mathrm{~cm}$ and $45 \mathrm{~cm}$, respectively. This variable indicates a greater proportion of leaves in forage canopy. Carvalho et al. (2015) stated that a greater amount of leaves reflects in a highly selective and preferential consumption by sheep, which select leaves rather than stems for being more nutritious and suitable to their needs.

Figure 1 displays the proportions of leaf blades, stem, and senescent material in plants of the three pre-grazing height treatments. Pastures managed at $25 \mathrm{~cm}$ pre-grazing height had the highest proportion of leaves, followed by those managed at $35 \mathrm{~cm}$ and $45 \mathrm{~cm}$, respectively. The higher luminosity in canopy of shorter pre-grazing heights is responsible for the greater appearance of leaves, given the decreased light interception (ARAÚJO et al., 2015). Therefore, it may be beneficial to productive system since leaf blade is the most nutritious and preferred plant component by animals (EMERENCIANO NETO et al., 2014). 
Conversely, pastures managed at $45 \mathrm{~cm}$ pregrazing canopy height had a higher proportion of senescent material and stem mass due to its greater elongation. Likewise, Macedo et al. (2015) found a higher proportion of senescent material with increasing canopy heights in Marandu grass, and they associated it with the higher self-shading and stem elongation that intensifies the senescence process of older leaves.

Figure 1. Relative proportions of leaf blade, stem, and senescent material; and leaf: stem ratio (L/S) of Megathyrsus maximus x $M$. infestum cv Massai according to the pre-grazing heights tested. Averages of three cuttings. Means followed by different letters within the same line differ from each other by the Tukey's test at $5 \%$ level of significance.

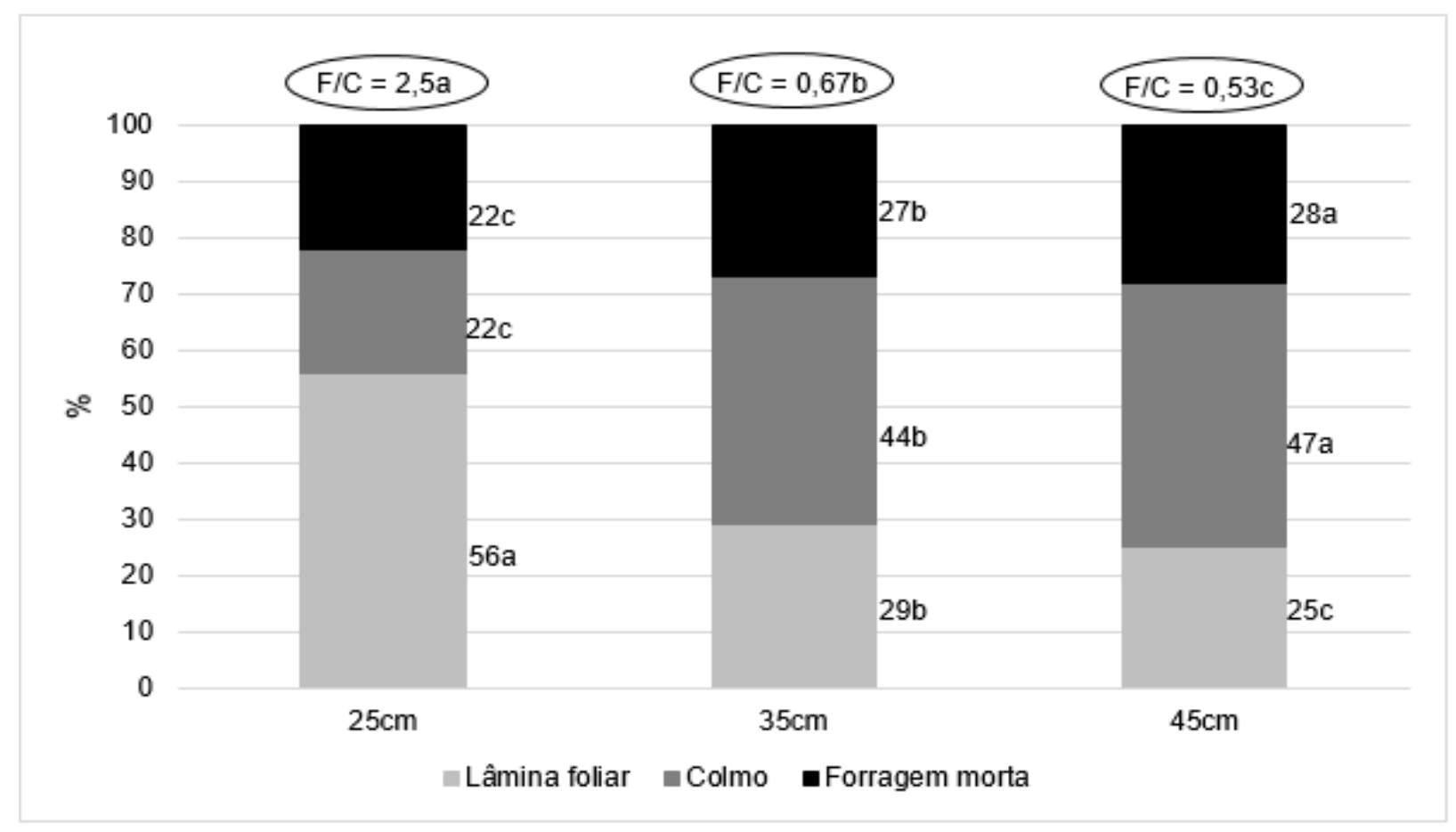

As can be observed in Table 3, TDM yield has a negative correlation with the proportion of leaf blades $(r=-0.95)$ but positive with those of stem $(r=0.96)$ and senescent material $(r=0.95)$. Therefore, the higher the total mass, the smaller the leaf proportion in forage canopy, whereas stem and senescent material proportions tend to increase. As a result, $\mathrm{L} / \mathrm{S}$ ratio also tends to decline $(\mathrm{r}=-0.98)$ with increasing total forage mass yield. 
Table 3. Pearson's correlation coefficients for canopy height (HEI), total dry matter yield (TDM), leaf blade percentage $(\% \mathrm{LB})$, stem percentage $(\% \mathrm{~S})$, senescent material percentage $(\% \mathrm{SM})$, forage density $(\mathrm{FD})$, leaf: stem ratio $(\mathrm{L} / \mathrm{S})$, available forage (AF), forage accumulation rate (FAR), and carrying capacity (CC) of Megathyrsus maximus $x$ M. infestum cv Massai.

\begin{tabular}{ccccccccccc}
\hline & HEI & TDM & $\% \mathrm{LB}$ & $\% \mathrm{~S}$ & $\% \mathrm{SM}$ & $\mathrm{FD}$ & $\mathrm{L} / \mathrm{S}$ & $\mathrm{AF}$ & $\mathrm{FAR}$ & $\mathrm{CC}$ \\
\hline $\mathrm{HEI}$ & 1 & $0.73^{* *}$ & $-0.89^{* *}$ & $0.89^{* *}$ & $0.90^{* *}$ & 0.42 & $-0.86^{* *}$ & 0.57 & 0.58 & 0.58 \\
$\mathrm{TDM}$ & & 1 & $-0.95^{* *}$ & $0.96^{* *}$ & $0.95^{* *}$ & $0.92^{* *}$ & $-0.98^{* *}$ & $0.98^{* *}$ & $0.98^{* *}$ & $0.93^{* *}$ \\
$\% \mathrm{LB}$ & & & 1 & $-0.99^{* *}$ & $-0.99^{* *}$ & $-0.75^{*}$ & $0.99^{* *}$ & $-0.86^{* *}$ & $-0.85^{* *}$ & $-0.87^{* *}$ \\
$\% \mathrm{~S}$ & & & & 1 & $0.99^{* *}$ & $0.76^{* *}$ & $-0.99^{* *}$ & $0.86^{* *}$ & $0.85^{* *}$ & $0.87^{* *}$ \\
$\% \mathrm{SF}$ & & & & & 1 & $0.73^{* *}$ & $-0.99^{* *}$ & $0.84^{* *}$ & $0.83^{* *}$ & $0.85^{* *}$ \\
$\mathrm{FD}$ & & & & & & 1 & $-0.79^{* *}$ & $0.98^{* *}$ & $0.98^{* *}$ & $0.98^{* *}$ \\
$\mathrm{~L} / \mathrm{S}$ & & & & & & & 1 & $-0.88^{* *}$ & $-0.89^{* *}$ & $-0.90^{* *}$ \\
$\mathrm{AF}$ & & & & & & & & 1 & $0.99^{* *}$ & $0.99^{* *}$ \\
$\mathrm{FAR}$ & & & & & & & & & 1 & $0.99^{* *}$ \\
$\mathrm{CC}$ & & & & & & & & & & 1 \\
\hline
\end{tabular}

* statistically significant at 5\% level; ** statistically significant at $1 \%$ level.

Positive correlations were found between plant canopy height and TDM yield $(r=0.73)$, and between plant canopy height and AF $(r=0.99)$; however, taller plants tend to have high stem masses $(\mathrm{r}=0.89)$. Thus, proper canopy height management is essential to increase FA, without significant losses in quality due to increased stem production. Brâncio et al. (2003) found a correlation of $r=0.70$ between canopy height and FA in Massai grass, whereas Macedo et al. (2015) found a correlation of $r=0.91$ for the same factors in Marandu grass.

As compared to pastures managed at $45 \mathrm{~cm}$, the higher stem mass at post-grazing of areas managed at $35 \mathrm{~cm}$ height proved that a high leafblade proportion and a great $\mathrm{F} / \mathrm{S}$ ratio at pre-grazing allowed the animals to select the most nutritive parts of the plant. According to Marques et al. (2012), sheep are very efficient in selecting food, ingesting only specific forage parts, even those of smaller sizes.

Leaf disappearance rate reached $70 \%$ in pastures managed at 25 and $35 \mathrm{~cm}$ height, while for those managed at $45 \mathrm{~cm}$ height was 59\%. Higher stem proportion in pasture with $45 \mathrm{~cm}$ in height should have jeopardized leaf selection by sheep, even if sheep are more selective animals. This fact was evidenced by Emerenciano Neto et al. (2014), who noted higher leaf-blade biomass at post-grazing, i.e., non-consumed forage, in plants with higher proportions of stems and senescent material. Hence, a higher proportion of such components may impair animal access to leaves at the canopy bottom.

FAR was higher in pastures managed at $35 \mathrm{~cm}$ pre-grazing height, followed by those with 45 and $25 \mathrm{~cm}$ height, respectively. Table 3 shows a clear correlation between FAR and TDM values $(r=0.98)$.

Table 4 exhibits the morphogenic characteristics of Massai grass at different canopy heights. LAR in pastures managed at $25 \mathrm{~cm}$ pre-grazing height was higher than those managed at $45 \mathrm{~cm}$ height. Higher canopy heights (e.g., $45 \mathrm{~cm}$ in height) reduce luminosity inside canopies and produce larger pseudostems, which increases distances for leaf expansion, resulting in lower LAR (SANTOS et al., 2011). The same authors observed a higher LAR in $U$. decumbens pastures managed at $15 \mathrm{~cm}$ in the winter compared to $25 \mathrm{~cm}$ height. Similarly, Sales et al. (2014) reported higher LAR and lower leaf-blade sizes in Marandu grass pastures managed at lower heights. 
Table 4. Leaf appearance rate (LAR - leaves tiller ${ }^{-1}$ day $\left.^{-1}\right)$, leaf elongation rate (LER - $\mathrm{cm} \mathrm{tiller}^{-1}$ day $\left.^{-1}\right)$, stem elongation rate (SER - cm tiller ${ }^{-1}$ day $^{-1}$ ), leaf senescence rate (LSR - $\mathrm{cm} \mathrm{tiller}^{-1}$ day $^{-1}$ ), phyllochron (days leaf tiller ${ }^{-1}$ ), number of live leaves (NLL - leaves tiller ${ }^{-1}$ ), defoliation intensity (DI - \%), and mean sheath length (SL - cm) of Megathyrsus maximus x M. infestum cv Massai according to the pre-grazing heights tested. Averages of three cuttings.

\begin{tabular}{|c|c|c|c|c|c|}
\hline \multirow{2}{*}{ Factor } & \multicolumn{3}{|c|}{ Pre-grazing canopy height $(\mathrm{cm})$} & \multirow{2}{*}{$\operatorname{Pr}>F$} & \multirow{2}{*}{$\mathrm{CV} \%$} \\
\hline & 45 & 35 & 25 & & \\
\hline LAR & $0.15 b$ & $0.16 \mathrm{ab}$ & $0.18 \mathrm{a}$ & $0.0019 * *$ & 23.67 \\
\hline LER & 2.48 & 2.38 & 2.31 & 0.5909 & 21.13 \\
\hline SER & $0.17 \mathrm{a}$ & $0.10 \mathrm{~b}$ & $0.07 \mathrm{c}$ & $<.0001 * *$ & 20.36 \\
\hline LSR & 0.19 & 0.12 & 0.02 & 0.7443 & 19.56 \\
\hline Phyllochron & $9.20 \mathrm{a}$ & $8.58 \mathrm{a}$ & $6.26 \mathrm{~b}$ & $0.0053 * *$ & 23.45 \\
\hline NLL & $2.9 \mathrm{~b}$ & $3.33 \mathrm{a}$ & $3.13 \mathrm{ab}$ & $0.0217^{*}$ & 20.76 \\
\hline DI & $25.83 b$ & $27.70 \mathrm{~b}$ & $39.12 \mathrm{a}$ & $<.0001 * *$ & 18.56 \\
\hline SL & $8.09 \mathrm{a}$ & $6.44 \mathrm{~b}$ & $4.55 c$ & $<.0001 * *$ & 21.67 \\
\hline
\end{tabular}

$\mathrm{CV}=$ Coefficient of variation. Means followed by different letters within the same line differ from each other by the Tukey's test $(\mathrm{P}<0.05)$.

Despite the above statements, no difference in LER was found among treatments. Greater elongation was already expected in treatments managed at greater heights since leaf-blade size and elongation rate tend to be higher when the rates of leaf appearance decrease (ANDRADE et al., 2005). This result can be explained by the slight difference in LAR among treatments, although statistically significant.

In assessing the effects of $5 \mathrm{~cm}$ and $15 \mathrm{~cm}$ postgrazing heights on the LAR of $U$. brizantha $\mathrm{cv}$. Marandu, Sales et al. (2014) stated that not only LER influences this characteristic but also sheath tube, which was reduced continuously at $5 \mathrm{~cm}$ postgrazing height. Our findings showed the same trend, in which sheath length was smaller in pastures managed at $25 \mathrm{~cm}$, followed by those at $35 \mathrm{~cm}$; therefore, leaves have a shorter distance until their appearance, as already emphasized by Oliveira et al. (2007).

As expected, phyllochron results were opposite to those of LAR, with the lowest values in pastures managed at $25 \mathrm{~cm}$, as this variable represents the number of days taken for the leaves to emerge. Araújo et al. (2015) and Carvalho et al. (2014) also reported an increase in phyllochron with greater sheath lengths. Plants with lower phyllochron may reach a maximum number of live leaves per tiller faster, allowing more frequent grazing to avoid senescence losses (ORRICO JÚNIOR et al., 2013).

As with LAR, the higher canopy shading by taller plants increases phyllochron since new leaf appearance may be delayed due to the increased sheath lengths surrounding apical meristems (CARVALHO et al., 2014). When the environment is modified and required growth conditions are affected, e.g., luminosity, plants activate mechanisms to reduce leaf appearance. This activation can directly affect phyllochron, and then plant metabolism starts to redirect photoassimilates for the preservation of living tissues (GALZERANO et al., 2013).

SER increased with increasing pre-grazing heights due to high light competition. According to Carvalho et al. (2014), increases in SER raises apical meristem to a height at which it becomes more susceptible to removal by grazing, which may interfere with the perenniality of forage. Lopes et al. (2013) reported an average SER of $0.166 \mathrm{~cm}$ tiller day $^{-1}$ in Massai grass, regardless of $\mathrm{N}$ rates used. 
Luna et al. (2014) observed low stem elongation $\left(0.06 \mathrm{~cm}\right.$ tiller day $\left.{ }^{-1}\right)$ in Massai grass managed at an average height of $20 \mathrm{~cm}$ in the rainy season, which is similar to that found here for pastures managed at $25 \mathrm{~cm}$.

Defoliation intensity increased when pasture was managed at $25 \mathrm{~cm}$ pre-grazing canopy height. This may have occurred due to the lower stem proportion under this condition. Thus, it allowed animals to graze to the base of clumps. Residues such as leaf litter, dead material or leaf sheaths may form a barrier to grazing the lower parts of forage (BRÂNCIO et al., 2003).

NLL was higher in pastures managed at 35 $\mathrm{cm}$ height, not differing from those managed at $25 \mathrm{~cm}$ height. Besides its direct relationship with leaf production potential, NLL is the fraction preferentially consumed by animals (LOPES et al., 2013). This variable was mainly affected by the higher appearance of leaves since senescence rate was similar in both canopy heights. As the increased shading at $45 \mathrm{~cm}$ had no effect on leaf senescence, what really occurred was a higher leaf appearance in other treatments. In this case, NLL may be crucial for pasture management during the decisionmaking process. The lower the LSR and the higher the NLL, the better the pasture nutritional quality will be. Forage mass must comprise living tissues capable of being converted into an animal product (GALZERANO et al., 2013).

While intense grazing tends to decrease LSR due to lesser shading by the remaining leaves, less intense grazing promotes increased shading on lower leaves, resulting in senescent leaves (CUTRIM JÚNIOR et al., 2010). According to Cândido et al. (2006), senescence rates equal to or close to zero indicate greater pasture use efficiency. When evaluating Massai grass in monoculture and silvopastoral pasture systems, Carvalho et al. (2014) also observed no difference in LSR and attributed it to the shortcoming of a 27-day rest interval to trigger foliar senescence. The same may have occurred in this study, which had an even shorter rest period (12 days). Senescence rate, residue effect, and rest period can be modified by plant adaptive capacity to ensure perenniality, counterbalancing across lower LAR and extended leaf lifespan in pastures managed at $45 \mathrm{~cm}$ canopy height (CÂNDIDO et al., 2006; CARVALHO et al., 2014).

Table 5 illustrates the chemical composition of Massai grass at different pre-grazing canopy heights. $\mathrm{DM}$ and $\mathrm{OM}$ were higher in pastures managed at 35 $\mathrm{cm}$ height, but not differing from those managed at $45 \mathrm{~cm}$ for DM. Caldeira (2016) found similar DM contents $\left(244 \mathrm{~g} \mathrm{~kg}^{-1}\right)$ in Massai grass.

A priori, the highest $\mathrm{CP}$ values were expected to be found in pastures managed at $25 \mathrm{~cm}$ pre-grazing height, as this management promoted higher L/S ratio (Figure 1); however, the values found were intermediate. Indeed, the highest $\mathrm{CP}$ content was observed in pastures managed at $35 \mathrm{~cm}$ pre-grazing height, while the lowest in those at $45 \mathrm{~cm}$. This inferior CP content in pastures managed at 45 $\mathrm{cm}$ height is related to the minor leaf blade yield. Leaf is the most nutritious plant part, therefore, with higher CP contents. Leaf nutrient content is slightly affected by pasture management (GURGEL et al., 2017); however, it has the ability to change leaf proportion in plant biomass, and therewith $\mathrm{CP}$ content. In this regard, Negri et al. (2013) stated that pasture management based on canopy height influences plant quality by altering its structure. Fontes et al. (2014) pointed out that higher leaf proportions in forage canopy improve the quality of pasture consumed by animals. This can be clearly observed in this study, where pastures managed at $35 \mathrm{~cm}$ height had increases of 39\% in CP content compared to those managed at $45 \mathrm{~cm}$ height. These contents may vary regardless of species, for example, Caldeira (2016) reported an average CP content of $126 \mathrm{~g} \mathrm{~kg}^{-1}$ in Massai grass, while Vargas Junior et al. (2013) recorded $93 \mathrm{~g} \mathrm{~kg}^{-1}$ for the same species during the rainy season. 
Table 5. Dry matter $(\mathrm{DM})$, organic matter $(\mathrm{OM})$, crude protein $(\mathrm{CP})$, ether extract $(\mathrm{EE})$, mineral matter $(\mathrm{MM})$, neutral detergent fiber (NDF), acid detergent fiber (ADF), total digestible nutrients (TDN), and in vitro organic matter digestibility (IVOMD) of Megathyrsus maximus x M. infestum cv Massai according to the pre-grazing heights tested. Averages of three cuttings.

\begin{tabular}{|c|c|c|c|c|c|}
\hline \multirow{2}{*}{ Factor $(\mathrm{g} / \mathrm{kg})$} & \multicolumn{3}{|c|}{ Pre-grazing canopy height $(\mathrm{cm})$} & \multirow{2}{*}{$\operatorname{Pr}>F$} & \multirow{2}{*}{$\mathrm{CV} \%$} \\
\hline & 45 & 35 & 25 & & \\
\hline $\mathrm{DM}$ & $244.90 \mathrm{ab}$ & $256.25 \mathrm{a}$ & $240.03 b$ & $0.0263^{*}$ & 3.94 \\
\hline OM & $194.88 b$ & $210.77 \mathrm{a}$ & $187.88 b$ & $0.0033 * *$ & 6.05 \\
\hline $\mathrm{CP}$ & $94.83 \mathrm{c}$ & $156.60 \mathrm{a}$ & $131.15 b$ & $<.0001^{* *}$ & 3.25 \\
\hline $\mathrm{EE}$ & 30.87 & 34.40 & 30.70 & 0.2083 & 9.52 \\
\hline MM & $50.03 \mathrm{ab}$ & $45.48 b$ & $52.15 \mathrm{a}$ & $0.0094 * *$ & 4.84 \\
\hline $\mathrm{NDF}$ & 779.43 & 779.45 & 770.70 & 0.0498 & 0.62 \\
\hline $\mathrm{ADF}$ & $397.78 a$ & $383.63 b$ & $387.73 b$ & $0.0038^{* *}$ & 0.44 \\
\hline TDN* & $467.37 \mathrm{c}$ & $501.49 b$ & $557.26 \mathrm{a}$ & $<.0001^{* *}$ & 1.64 \\
\hline IVOMD (\%) & $48.41 \mathrm{c}$ & $51.77 \mathrm{~b}$ & $57.26 \mathrm{a}$ & $0.0028 * *$ & 5.74 \\
\hline
\end{tabular}

$\mathrm{CV}=$ Coefficient of variation. Means followed by different letters within the same line differ from each other by the Tukey's test $(\mathrm{P}<0.05)$. *TDN $=-2.49+1.0167$ IVOMD (CAPPELLE et al., 2001).

TDN content reached its peak in pastures managed at $25 \mathrm{~cm}$ pre-grazing canopy height, whereas intermediate values were observed in those managed at $35 \mathrm{~cm}$ height. The lowest values were reported in pastures kept at $45 \mathrm{~cm}$ pre-grazing canopy height, following the same behavior observed for IVOMD. Taller plants tend to produce less young tissue which, in turn, is more nutritious than the older and lignified ones. According to the NRC (2007), ruminants would rather select the plant part of better quality in terms of nutrients, protein, and digestibility than the total forage biomass available.

Leaf yield has an inverse correlation with fiber production, that is, the higher the leaf blade yield, the lower the amount of fiber. However, NDF levels showed no significant difference among treatments. Pastures managed at $45 \mathrm{~cm}$ height had the highest ADF content among the tested treatments. ADF values found in this study are similar to those obtained by Fernandes et al. (2014) and Vargas Junior et al. (2013) (382 and $399 \mathrm{~g} \mathrm{~kg}^{-}$ ${ }^{1}$, respectively). According to Gurgel et al. (2017), there is a correlation between leaf blade yield and simultaneous increase of CP content and reduction of ADF since leaves have higher contents of CP and lower of ADF if compared to the other parts of the plant.

According to Valente et al. (2010), taller plants have reduced protein contents as a result of increases in lignin content and cell wall thickness, which is less digestible and occurs due to an increase in stem yield; by contrast, shorter plants have no need for greater structure to support biomass. For these same authors, increases in ADF content can be associated with the remaining leaves in pasture managed at greater heights, what reduces ecosystem quality over time. The higher the ADF content in forages, the higher the lignin content and hence the lower the substrate availability for ruminal digestion (MAGALHÃES et al., 2015).

Moreover, ADF content is an indicator of forage energy and digestibility since the lower the ADF the higher the dietary energy and the lower the lignin content (MAGALHÃES et al., 2015). Forages with higher ADF contents also had a lower $\mathrm{CP}$ value and lower digestibility. Chaves et al. (2016) verified a decrease in digestibility of elephant grass with increasing light interception by forage canopy. They 
also associated this decline with increased values of stem proportion, NDF and ADF levels, as well as decreased CP contents. Digestibility rates found in our study corroborate those of Caldeira (2016), who reported percentages of 48.55, 50.56, and 51.60\% for CP contents of 98.4, 130.8, and $167.5 \mathrm{~g} \mathrm{~kg}^{-1}$ respectively, both in the same season and Brazilian ecosystem (Cerrado). Distinctly, our findings on NDF (700.0, 701.2 and $666.8 \mathrm{~g} \mathrm{~kg}^{-1}$ ) and ADF (339.0, 360.8 and $313.3 \mathrm{~g} \mathrm{~kg}^{-1}$ ) were lower than those observed by Caldeira (2016).

Table 6 shows the averages of sheep performance grazing at pastures with different pre-grazing canopy heights. Grazing efficiency (GE) differed among treatments, increasing with decreasing pregrazing heights. The highest GE was observed in pastures managed at $25 \mathrm{~cm}$ height, while medium and lowest values were observed for those managed at 35 and $45 \mathrm{~cm}$ height, respectively. Forage stem proportion increases with canopy height, making it difficult for animals to access the lower stratum of canopies, and hence reducing grazing efficiency.

Feed intake was higher for sheep grazing pastures managed at $35 \mathrm{~cm}$ pre-grazing canopy height. This owes to the higher CP contents since NDF levels had no difference among treatments. Besides, increased $\mathrm{ADF}$ levels, as in pastures managed at $45 \mathrm{~cm}$ height, may inhibit feed ingestion due to lower digestibility and forage passage rate (EMERENCIANO NETO, 2015). Other factors also influence animal feed intake such as $\mathrm{L} / \mathrm{S}$ ratio, which, in plants managed at $45 \mathrm{~cm}$, was significantly low. When available, the amount of forage ingested by sheep is more influenced by green mass (mainly leaf blade) than is by the total amount of biomass (RIBEIRO et al., 2014). As earlier discussed, pastures managed at $45 \mathrm{~cm}$ height had lower L/S ratio and higher senescent material proportion, which might have reduced feed intake.

Table 6. Initial body weight (Initial BW), final body weight (Final BW), grazing efficiency (GE), forage dry matter intake in $\mathrm{kg}$ day $^{-1}\left(\mathrm{DM} \mathrm{kg} \mathrm{day}{ }^{-1}\right.$ ), as a percentage of body weight (DM\% BW) and in g per kg of metabolic weight $\left(\mathrm{DM} \mathrm{g} \mathrm{kg}{ }^{0.75}\right)$, total weight gain (WG), average daily weight gain (ADWG), average daily weight gain per hectare (ADWGA), and stocking rate (SR) in sheep grazing Megathyrsus maximus $x$ M. infestum cv Massai at different pregrazing heights.

\begin{tabular}{|c|c|c|c|c|c|}
\hline \multirow{2}{*}{ DM intake } & \multicolumn{3}{|c|}{ Pre-grazing canopy height $(\mathrm{cm})$} & \multirow{2}{*}{$\operatorname{Pr}>\mathrm{F}$} & \multirow{2}{*}{$\mathrm{CV} \%$} \\
\hline & 45 & 35 & 25 & & \\
\hline Initial BW (kg) & 21.367 & 24.133 & 22.167 & 0.9055 & 26.08 \\
\hline Final BW (kg) & 23.933 & 26.400 & 23.983 & 0.1921 & 26.13 \\
\hline GE $\%$ & $45.250 \mathrm{c}$ & $52.000 \mathrm{~b}$ & $65.750 \mathrm{a}$ & $<.0001 * *$ & 5.89 \\
\hline DM kg day ${ }^{-1}$ & $0.820 \mathrm{~b}$ & $1.037 \mathrm{a}$ & $0.779 \mathrm{c}$ & $<.0001 * *$ & 7.09 \\
\hline DM \%BW & $3.428 b$ & $3.928 \mathrm{a}$ & $3.248 \mathrm{c}$ & $0.0001 * *$ & 7.03 \\
\hline $\mathrm{DM} \mathrm{g} \mathrm{kg}^{0.75}$ & $77.782 b$ & $89.038 \mathrm{a}$ & $71.880 \mathrm{c}$ & $<.0001 * *$ & 7.25 \\
\hline WG $(\mathrm{kg})$ & 1.816 & 2.567 & 2.267 & 0.2653 & 21.36 \\
\hline ADWG (kg) & 0.062 & 0.073 & 0.065 & 0.2653 & 19.23 \\
\hline DWGA $\left(\mathrm{kg} \mathrm{ha}^{-1}\right)$ & $3.667 b$ & $6.996 \mathrm{a}$ & $3.238 b$ & $0.0039 * *$ & 21.36 \\
\hline $\operatorname{SR}\left(\mathrm{AU} \mathrm{ha}{ }^{-1}\right) *$ & $3.935 b$ & $5.324 \mathrm{a}$ & $2.544 \mathrm{c}$ & 0.0011 & 5.54 \\
\hline
\end{tabular}

$\mathrm{CV}=$ Coefficient of variation. Means followed by different letters within the same line differ from each other by the Tukey's test $(\mathrm{P}<0.05)$. *1 $\mathrm{AU}=450 \mathrm{~kg}$ of body weight. 
Animal consumption has a positive correlation with forage availability (CARVALHO et al., 2015; GONTIJO NETO et al., 2006), therefore, forage supply may impair selective consumption and prehension. The forage availability and supply were significantly lower in pastures managed at $25 \mathrm{~cm}$ pre-grazing height, which can be attributed to the lower consumption of animals.

Comparisons among all treatments showed no significant difference for $\mathrm{WG}$ and ADWG. The latter is related not only to forage quality but also to the chances of selecting diet under grazing conditions (MACHADO et al., 2008). Despite the better quality of forage cut at 35 and $25 \mathrm{~cm}$ heights, this selective behavior was affected. In pastures managed at $35 \mathrm{~cm}$ height, such behavior was reduced because additional animals were included once biomass yield and available forage increased. In contrast, when plants were cut at $25 \mathrm{~cm}$ height, this reduction in selective intake was caused due to a lower availability of forage for each animal.

Regarding ADWGA, the higher carrying capacity of pasture managed at $35 \mathrm{~cm}$ height provided higher weight gains per hectare. In other words, even if individual gains were equal among animals, this treatment was more efficient to support a greater number of animal animals per area and increase weight gain. This outcome is of great interest for sheep meat industry. Emerenciano Neto et al. (2014) found a value for carrying capacity equivalent to 2.36 AU ha-1 for Massai grass managed at $52.65 \mathrm{~cm}$ height under rotational grazing. This value is lower than the stocking rate found for the $35 \mathrm{~cm}$ pregrazing height in our study, which was the highest among all tested treatments but lower than that for $45 \mathrm{~cm}$ height.

\section{Conclusions}

Among the evaluated pre-grazing canopy heights, the management of Massai grass at 35 $\mathrm{cm}$ is the most indicated to raise sheep under rotational grazing system due to its improved forage availability and nutritional quality, which, in turn, allows greater weight gain per area.

Despite being the highest pre-grazing canopy height tested, $45 \mathrm{~cm}$ promoted a lower dry matter yield than that of the intermediate height, and lower forage quality if compared to both $35 \mathrm{~cm}$ and $25 \mathrm{~cm}$. If compared to $35 \mathrm{~cm}$, the lower dry matter yield of plants managed at $45 \mathrm{~cm}$ height resulted in low weight gain per hectare.

Despite its good quality, pastures managed at 25 $\mathrm{cm}$ pre-grazing canopy height had reduced biomass yield if compared to the other treatments $(35 \mathrm{~cm}$ and $45 \mathrm{~cm}$ height), thus reducing weight gains per area.

\section{References}

AMORIM, D. S.; SILVA, A. L.; SOUSA, S. V.; SOUSA, P. H. A. A.; LIMA, B. S. L.; REIS, A. L. A. Caracterização e restrições de forrageiras indicadas para diferentes espécies em animais de produção - Revisão. Revista Eletrônica Científica, Porto Alegre, v. 3, n. 1, p. 215-237, 2017. DOI: /10.21674/2448-0479.31.215-237

ANDRADE, A. C.; FONSECA, D. M.; LOPES, R. S.; NASCIMENTO JÚNIOR, D.; CECON, P. R.; QUEIROZ, D. S.; PEREIRA, D. H.; REIS, S. T. Características morfogênicas e estruturais do capim-elefante Napier adubado e irrigado. Ciência e Agrotecnologia, Lavras, v. 29, n. 1, p. 150-159, 2005.

ARAÚJO, R. P.; SOUZA, B. B.; ROBERTO, J. V. B.; DANTAS, N. L. B.; OLIVEIRA, G. J. C.; BATISTA, L. F.; CORDÃO, M. A. Medidas corporais e da carcaça de ovinos suplementados com diferentes níveis de sal forrageiro de faveleira. Revista Cientifica de Produção Animal, Areia, v. 17, n. 1, p. 1-6, 2015. DOI: $10.15528 / 3812$

BERNARDINO, F. S.; GARCIA, R. Sistemas Silvipastoris. Pesquisa Florestal Brasileira, Colombo, v. 1, n. 60, p. 77-88, 2009. Suplemento. DOI: 10.4336/2009. pfb.60.77

BRÂNCIO, P. A.; EUCLIDES, V. P. B.; NASCIMENTO JÚNIOR, D.; FONSECA, D. M.; ALMEIDA, R. G.; MACEDO, M. C. M.; BARBOSA, R. A. Avaliação de três cultivares de Panicum maximum Jacq. sob pastejo: disponibilidade de forragem, altura do resíduo póspastejo e participação de folhas, colmos e material morto. 
Revista Brasileira de Zootecnia, Viçosa, MG, v. 32, n. 1, p. 55-63, 2003.

CALDEIRA, R. R. Avaliação da produção e da qualidade do capim Panicum maximum cv Massai. 2016. Dissertação (Mestrado em Ciência Animal) Universidade de Brasília, Brasília.

CÂNDIDO, M. J. D.; SILVA, R. G.; NEIVA, J. N. M.; FACÓ, O.; BENEVIDES, Y. I.; FARIAS, S. F. Fluxo de biomassa em capim-tanzânia pastejado por ovinos sob três períodos de descanso. Revista Brasileira de Zootecnia, Viçosa, MG, v. 35, n. 6, p. 2234-2242, 2006.

CAPPELlE, E. R.; VALADARES FILHO, S. C.; SILVA, J. F. C. Estimativas do valor energético a partir de características químicas e bromatológicas dos alimentos. Revista Brasileira Zootecnia, Viçosa, MG, v. 30 , n. 6, p. 1837-1856, 2001. DOI: 10.1590/S151635982001000700025

CARVALHO, D. M. G.; CABRAL, L. S.; SILVA, J. J.; ABREU, J. G.; GALATI, R. L.; GENTILE, G. G. P.; CAMARGO, L. M.; SOARES, J. Q.; RUFINO JÚNIOR, J. Suplementos para terminação de ovinos em pasto de Brachiaria brizantha cv. Marandu. Semina: Ciências Agrárias, Londrina, v. 36, n. 1, p. 313-326, 2015. DOI: 10.5433/1679-0359.2015v36n1p313

CARVALHO, W. F.; MOURA, R. L.; SANTOS, M. S.; SILVA, S. F.; LEAL, T. M. Morfogênese e estrutura de capim-massai em diferentes sistemas de cultivo sob pastejo. Revista Brasileira de Agropecuária Sustentável, Viçosa, MG, v. 4, n. 1, p. 28-37, 2014.

CHAVES, C. S.; RIBEIRO, K. G.; GOMIDE, C. A. M.; PACIULLO, D. S. C.; MORENZ, M. J. F.; GAMA, D. S. Valor nutritivo e cinética de degradação in vitro de genótipos de capim-elefante (Penissentum purpureum Schumach) sob dois intervalos de desfolhação e duas alturas de resíduos pós-pastejo. Arquivo Brasileiro de Medicina Veterinária e Zootecnia, Belo Horizonte, v. 68, n. 5, p. 1351-1359, 2016.

COSTA, N. L.; PAULINO, V. T.; MAGALHÃES, J. A.; RODRIGUES, B. H. N.; SANTOS, F. J. S. Eficiência do nitrogênio, produção de forragem e morfogênese do capim-massai sob adubação. Nucleus, Ituverava, v. 13, n. 2, p. 173-182, 2016. DOI: 10.3738/1982.2278.1695

CUTRIM JÚNIOR, J. A. A.; CÂNDIDO, M. J. D.; VALENTE, B. S. M.; CARNEIRO, M. S. S.; CARNEIRO, H. A. V.; CIDRÃO, P. M. L. Fluxo de biomassa em capim-tanzânia sob três frequências de desfolhação e dois resíduos pós-pastejo. Revista Brasileira de Saúde e Produção Animal, Salvador, v. 11, n. 3, p. 618-629, 2010.

EMERENCIANO NETO, J. V. Produção vegetal $e$ animal e composição química do solo em pastos de capim-massai manejado sob alturas de pré-pastejo. 2015. Tese (Doutorado em Zootecnia) - Universidade Federal de Minas Gerais, Belo Horizonte.

EMERENCIANO NETO, J. V.; DIFANTE, G. S.; AGUIAR, E. M.; FERNANDES, L. S.; OLIVEIRA, H. C. B.; SILVA, M. G. T. Performance of meat sheep, chemical composition and structure of tropical pasture grasses managed under intermittent capacity. Bioscience Journal, Uberlândia, v. 30, n. 3, p. 834-842, 2014.

EMERENCIANO NETO, J. V.; PEREIRA, G. F.; DIFANTE, G. S.; OLIVEIRA, L. G.; LIMA, A. R.; SANTOS, W. R.; GURGEL, M. F. Produção e estrutura de pastos de capim-massai adubado com dejetos da produção animal. Boletim de Indústria Animal, Nova Odessa, v. 73, n. 2, p. 111-117, 2016.

EMPRESA BRASILEIRA DE PESQUISA AGROPECUÁRIA - EMBRAPA. Sistema brasileiro de classificação de solos. 3. ed. Brasília: EMBRAPA-CNPS, 2013. 353 p. (Produção de Informação; Paraná).

FERNANDES, F. D.; RAMOS, A. K. B.; JANK, L.; CARVALHO, M. A.; MARTHA JUNIOR, G. B.; BRAGA, G. J. Forage yield and nutritive value of Panicum maximum genotypes in the Brazilian savannah. Scientia Agricola, Piracicaba, v. 71, n. 1, p. 23-29, 2014. DOI: $10.1590 / \mathrm{S} 0103-90162014000100003$

FONTES, J. G. G.; FAGUNDES, J. L.; BACKES, A. A.; BARBOSA, L. T.; CERQUEIRA, E. S. A.; SILVA, L. M.; MORAIS, J. A. S.; VIEIRA, J. S. Acúmulo de massa em cultivares de Brachiaria brizantha submetida a intensidades de desfolhação. Semina: Ciências Agrárias, Londrina, v. 35, n. 3, p. 1425-1438, 2014. DOI: 10.5433/1679-0359.2014v35n3p1425

GALZERANO, L.; MALHEIROS, E. B.; RAPOSO, E.; MORGADO, E. S.; RUGGIERI, A. C. Morphogenetic and structural characteristics of xaraés palisadegrass subjected to grazing intensities. Semina: Ciências Agrárias, Londrina, v. 34, n. 4, p. 1879-1890, 2013. DOI: 10.5433/1679-0359.2013v34n4p1879

GARCIA, C. A.; CIDRÃO, K.; SPERS, R. C.; COLOMBO, D.; TREVIZAN, B. A. Produção de cordeiros em regime de pasto, com suplementação mineral e proteica em cochos privativos. Unimar Ciências, Marília, v. 25, n. 2, p. 57-67, 2016.

GOERING, H. K.; VAN SOEST, P. J. Forage fiber analysis (Apparatus, reagents, procedures and some applications). Washington: USDA, 1970. 379 p.

GONTIJO NETO, M. M.; EUCLIDES, V. P. B.; NASCIMENTO JÚNIOR, D.; MIRANDA, L. F.; FONSECA, D. M.; OLIVEIRA, M. P. Consumo e tempo diário de pastejo por novilhos Nelore em pastagem de 
capim-tanzânia sob diferentes ofertas de forragem. Revista Brasileira de Zootecnia, Viçosa, MG, v. 35, n. 1, p. 60-66, 2006.

GURGEL, A. L. C.; DIFANTE, G. S.; EMERENCIANO NETO, J. V.; SOUZA, J. S.; VERAS, E. L. L.; COSTA, A. B. G.; CARVALHO NETO, R. T.; FERNANDES, L. S.; CUNHA, J. C.; ROBERTO, F. F. S. Estrutura do pasto e desempenho de ovinos em capim-massai na época seca em resposta ao manejo do período das águas. Boletim de Indústria Animal, Nova Odessa, v. 74, n. 2, p. 86-95, 2017. DOI: $10.17523 /$ bia.v74n2p106

INSTITUTO NACIONAL DE METEOROLOGIA - INMET. Rede de estações climatológicas. Brasília: INMET, 2018. Disponível em: <http://www.inmet.gov. br/portal/index. php?r=home/index $>$. Acesso em: 7 mar. 2018.

LIMA, C. B.; COSTA, T. G. P.; NASCIMENTO, T. L.; LIMA JÚNIOR, D. M.; SILVA, M. J. M. S.; MARIZ, T. M. A. Comportamento ingestivo e respostas fisiológicas de ovinos em pastejo no semiárido. Journal Animal Behavior Biometeorology, Mossoró, v. 2, n. 1, p. 26-34, 2014.

LOPES, M. N.; CÂNDIDO, M. J. D.; POMPEU, R. C. F. F.; SILVA, R. G.; LOPES, J. W. B.; FERNANDES, F. R. B.; LACERDA, C. F.; BEZERRA, F. M. L. Fluxo de biomassa em capim-massai durante o estabelecimento e rebrotação com e sem adubação nitrogenada. Revista Ceres, Viçosa, MG, v. 60, n. 3, p. 363-371, 2013.

LUNA, A. A.; DIFANTE, G. S.; MONTAGNER, D. B.; EMERENCIANO NETO, J. V.; ARAÚJO, I. M. M.; OLIVEIRA, L. E. C. Características morfogênicas e acúmulo de forragem de gramíneas forrageiras, sob corte. Bioscience Journal, Uberlândia, v. 30, n. 6, p. 1803-1810, 2014.

MACEDO, E. O.; OLIVEIRA, M. E.; SILVA, P. C.; RIBEIRO, A. M.; OLIVEIRA, G. L.; ANDRADE, A. C.; RODRIGUES, M. M. Consumo e comportamento ingestivo de cabras em pasto de capim-marandu. Semina: Ciências Agrárias, Londrina, v. 36 , n. 3 , p. $2175-2184$, 2015. Suplemento 1. DOI: 10.5433/1679-0359.2015v36n3Sup11p2175

MACHADO, L. A. Z.; FABRICIO, A. C.; GOMES, A.; ASSIS, P. G. G.; LEMPP, B.; MARASCHIN, G. E. Desempenho de animais alimentados com lâminas foliares em pastagem de capim-marandu. Pesquisa Agropecuária Brasileira, Brasília, v. 43, n. 11, p. 16091616, 2008.

MAGALhÃES, J. A.; CARNEIRO, M. S. S.; ANDRADE, A. C.; PEREIRA, E. S.; RODRIGUES, B. H. N.; COSTA, N. L.; FOGAÇA, F. H. S.; CASTRO, K.
N. C.; TOWNSEND, C. R. Composição bromatológica do capim-Marandu sob efeito de irrigação e adubação nitrogenada. Semina: Ciências Agrárias, Londrina, v. 36, n. 2, p. $933-942$, 2015.DOI: $10.5433 / 1679-0359.2015 v 3$ 6n2p933

MARQUES, J. A.; VENCESLAU, E. A. J.; EIRAS, C. E.; STRADA, E. S. O.; PINHEIRO, E. E. G.; SILVA, P. A.; PRADO, I. N.; MATOS, L. H. A. Comportamento ingestivo de cordeiros Santa Inês em pastagem de Panicum maximum cv. Aruana: aspectos metodológicos. Campo Digital, Campo Mourão, v. 7, n. 1, p. 45-52, 2012.

MYERS, W. D.; LUDDEN, P. A.; NAYIGIHUGU, V. WESS, B. H. A procedure for the preparation of a quantitative analysis of samples for titanium dioxide. Journal of Animal Science, Oxford, v. 82, n. 1. p. 179183, 2004. DOI: $10.2527 / 2004.821179 x$

NEGRI, R.; SANTOS, G. B.; MACEDO, V. P.; SILVEIRA, M. F.; BIDIN, V. Comportamento ingestivo de cordeiras em pastagem de capim Aruana manejado em diferentes alturas. Synergismus Scyentifica, Pato Branco, v. 8, n. 2, p. 1-3, 2013.

NUTRITION RESEARCH COUNCIL - NRC. Nutrient of small ruminants: sheep, goats, cervids, and new world camelids. Washington: National Academy Press, 2007. $384 \mathrm{p}$.

OLIVEIRA, A. B.; PIRES, A. J. V.; MATOS NETO, U.; CARVALHO, G. G. P.; VELOSO, C. M.; SILVA, F. F. Morfogênese do capim-tanzânia submetido a adubações e intensidades de corte. Revista Brasileira de Zootecnia, Viçosa, MG, v. 36, n. 4, p. 1006-1013, 2007. Suplemento.

ORRICO JÚNIOR, M. A. P.; ORRICO, A. C. A.; CENTURION, S. R.; SUNADA, N. S.; VARGAS JUNIOR, F. M. Características morfogênicas do capimpiatã submetido à adubação com efluentes de abatedouro avícola. Ciência Rural, Santa Maria, v. 43, n. 1, p. 158163, 2013.

RIBEIRO, P. P.; CABRAL, L. S.; ZERVOUDAKIS, J. T.; MIRANDA, L.; ABREU, J. G.; RODRIGUES, R. C.; MORENZ, M. J. F.; OLIVEIRA, L. S.; TOLEDO, C. L. B. Porcentagem de proteína em suplementos para ovinos mantidos em pasto de capim-aruana na época seca. Arquivo Brasileiro de Medicina Veterinária e Zootecnia, Belo Horizonte, v. 66, n. 6, p. 1779-1786, 2014. DOI: $10.1590 / 1678-5357$

RODRÍGUEZ, N. M.; SALIBA, E. O. S.; GUIMARAES JÚNIOR, R. Uso de indicadores para estimativa de consumo a pasto e digestibilidade. In: REUNIÃOANUAL DA SOCIEDADE BRASILEIRA DE ZOOTECNIA, 43., 2006, João Pessoa. Anais... João Pessoa: SBZ, 2006. CD-ROM. 
SALES, E. C. J.; REIS, S. T.; ROCHA JÚNIOR, V. R.; MONÇÃO, F. P.; MATOS, V. M.; PEREIRA, D. A.; AGUIAR, A. C. R.; ANTUNES, A. P. S. Características morfogênicas e estruturais da Brachiaria brizantha cv. Marandu submetida a diferentes doses de nitrogênio e alturas de resíduos. Semina: Ciências Agrárias, Londrina, v. 35 , n. 5, p. 2673-2684, 2014.

SAMPAIO, A. F.; MENDES, F. B. L.; SANTANA JÚNIOR, H. A.; SANTANA, E. O. C.; SILVA, R. R.; SILVA, F. F. Correlação entre comportamento ingestivo e consumo de nutrientes em vacas a pasto. Revista Cientifica de Produção Animal, Areia, v. 18, n. 2, p. 110120, 2016. DOI: $10.15528 / 5645$

SANTOS, M. E. R.; FONSECA, D. M.; GOMES, V. M.; GOMIDE, C. A. M.; NASVIMENTO JÚNIOR, D.; QUEIROZ, D. S. Capim-braquiária sob lotação contínua e com altura única ou variável durante as estações do ano: morfogênese e dinâmica de tecidos. Revista Brasileira de Zootecnia, Viçosa, MG, v. 40, n. 11, p. 2323-2331, 2011.

SILVA, D. J.; QUEIROZ, A. C. Análises de alimentos: métodos químicos e biológicos. 3. ed. Viçosa, MG: Editora UFV, 2002. 235 p.

STATISTICAL ANALYSIS SYSTEM INSTITUTE - SAS INSTITUTE. SAS/STATTM. User's guide statistics. 6.4 ed. Cary: SAS Institute, 1999.
STEEL, R. G. D.; TORRIE, J. H.; DICKEY, D. A. Principles and procedures of statistics: a biometrical approach. New York: McGraw Hill Book, 1997. 666 p.

TILLEY, J. M. A.; TERRY, R. A. A two-stage technique for the in vitro digestion of forage crops. Nature, London v. 18 , n. 2 , p. $104-111,1963$. DOI: $10.1111 /$ j.13652494.1963.tb00335.x

VALENTE, B. S. M.; CÂNDIDO, M. J. D.; CUTRIM JUNIOR, J. A. A.; PEREIRA, E. S.; BOMFIM, M. A. D.; FEITOSA, J. V. Composição químicobromatológica, digestibilidade e degradação in situ da dieta de ovinos em capim-tanzânia sob três frequências de desfolhação. Revista Brasileira de Zootecnia, Viçosa, MG, v. 39, n. 1, p. 113-120, 2010.

VAN SOEST, P. J. Nutritional ecology of the ruminants. $2^{\text {th }}$ ed. Ithaca: Cornell University, 1994. $476 \mathrm{p}$.

VARGAS JUNIOR, F. M.; SOCORRO, M. M.; SETTI, J. C. A.; PINTO, G. S.; MARTINS, C. F.; COSTA, J. A. A.; MAGRIN, M. N.; CAMILO, F. R.; MONTAGNER, D. B. Disponibilidade de valor nutritivo de gramíneas tropicais sob pastejo com ovinos. Archivos de Zootecnia, Córdoba, v. 62, n. 238, p. 295-298, 2013. DOI: 10.4321/ S0004-05922013000200016 
